\title{
УРОЖАЙНІСТЬ ТА ПОКАЗНИКИ ЯКОСТІ ПШЕНИЦІ ОЗИМОЇ ЗАЛЕЖНО ВІД СИСТЕМ ОСНОВНОГО ОБРОБІТКУ ГРУНТУ ТА УДОБРЕННЯ
}

\begin{abstract}
K. С. КАРАБАЧ, кандидат сільськогосподарських наук, дочент ORCID https://orcid.org/0000-0002-7706-231X Національний університет біоресурсів і природокористування України E-mail: karabach_ks@ukr.net

Анотація. Досліджено вплив застосування різних систем основного обробітку грунту (полищева, мілка безполицева, глибока безполицева) та рівнів удобрення на урожайність та якісні показники зерна пшениці озимої. Дослідженнями встановлено, що в умовах Правобережного Лісостепу України систематичний безполицевий обробіток грунту підвищує урожайність та якість зерна пшениці озимої на всіх рівнях удобрення, порівняно із традиційним полицевим. Внесення органічних і мінеральних добрив на чорноземі типовому позитивно впливає на урожайність пшениці озимої, підвищуючи ії порівняно з контролем на 0,28-0,84 $\mathrm{m} / 2 a$ за оранки, на 0,36-1,26 m/га за глибокого безполицевого обробітку і на 0,4-1,55 m/га - за мілкого. Виявлено, що найвищу урожайність культури $(4,72$ $\mathrm{m} / 2 a$ ) отримано за мілкого плоскорізного обробітку грунту на фоні органомінерального удобрення із застосуванням гною, а за глибокого безполицевого обробітку цей показник був лише на 3 \% нижчим. Загалом уміст білка та клейковини на удобрюваних варіантах відповідали нормам якості сильної, а на контролі - цінної пшениці. Найвищі якісні показники зерна пшениці озимої відмічені на варіанті з традиційним органо-мінеральним удобренням (Гній + NPK) за мілкого безполицевого обробітку: вміст білка склав 15,5\%, а вміст клейковини - 31,9\%, що відповідає І групі якості.
\end{abstract}

Ключові слова: пшениця озима, обробіток, грунт, добрива, якість зерна

\section{Актуальність.}

Україна - велика аграрна держава. Протягом останніх років вона упевнено заявляє про себе на світовому ринку зерна. За даними Міністерства розвитку економіки, торгівлі і сільського господарства, експорт продукції аграрного сектору протягом січ- ня-липня 2019 року становив майже 12 мільярдів дол., або 41,7 \% загального експорту України. Попри не зовсім оптимістичні весняні прогнози фахівців, Україна в цьому році знову вийде на черговий рекордний урожай зернових. За різними оцінками аналітиків, цей показник може бути від 71 до 74,3 млн т. Валовий збір озимої пшениці, яка $є$ основною зерновою 
культурою в Україні, цьогоріч буде на рівні 27,55 млн т, що на 15,3 \% більше, ніж у 2018 (Громов О., 2019). Понад $70 \%$ урожаю цієї культури - це продовольче зерно, але воно, нажаль, не завжди відповідає стандартам якості. На це впливає недостатній рівень землеробства, недотримання технології вирощування, а також несприятливі погодні умови (Лебідь Є.М., Черенков А. В., Солодушко М. M., 2008). Погіршення екологічного стану довкілля в Україні теж вимагає зменшення або нівелювання шкідливого впливу антропогенних факторів. Тому, проблема поліпшення якості зерна пшениці озимої та іiї хлібопекарських показників, водночас зі збільшенням зерновиробництва, залишається актуальною, особливо за умов недостатнього внесення добрив та зміни клімату в останні роки. У країні розроблені, обгрунтовані й уже використовуються грунтозахисні енерго-, ресурсо- і вологозберігаючі технології вирощування сільськогосподарських культур. Швидке й цілеспрямоване їхнє впровадження дасть змогу ще підняти врожайність сільськогосподарської продукції, що зробить Україну однією з провідних держав-експортерів зерна на світовому ринку.

\section{Аналіз останніх досліджень ма публікацій.}

Забезпечення потреб населення України в продовольчому та фуражному зерні та експорті його за кордон можливе лише за умови стійкого та прискореного нарощування його виробництва $з$ використанням сучасних технологій, сортів та підбором найкращих попередників озимої пшениці у сівозміні.
В умовах зростання вартості мінеральних добрив, паливо-мастильних матеріалів та інших енерговитрат постає питання необхідності їх зменшення в технологіях вирощування сільськогосподарських культур. За таких умов раціональне ведення землеробства можливе за рахунок підвищення ефективності удобрення, складовою частиною якої є біологічні сівозміни та ресурсозберігаючі грунтозахисні системи обробітку грунту.

На сьогоднішній день підвищення врожаю сільськогосподарських культур під впливом обробітку грунту без обертання скиби констатується в низці літературних джерел (Марковська О. С., 2017; Погромська Я., 2019; Вожегова Р.А., Кривенко А.І., 2019). Але наявність даних як позитивного, так і негативного впливу мінімізації обробітку на врожайність культур свідчать про складність цього питання (Малярчук М. П., Вожегова Р. А., Марковська О. Є., 2012; Вожегова Р. А., Сташук В. А., Заришняк А. С., 2014).

Багато авторів вважають за необхідне чергувати в сівозміні оранку 3 безполицевим обробітком, що сприяє рівномірному розподілу поживних елементів профілем орного шару, а також накопиченню гумусу в шарі грунту 10 20 см на 0,04-0,06 \%, а в шарі 0-10 cм - 0,16-0,21 \% (Коломієць М.В.).

Тому, питання наукового обгрунтування технологій вирощування, що базуються на різних способах і глибині основного обробітку 3 використанням грунтообробних знарядь, які дозволяють підвищити врожайність сільськогосподарських культур, зменшити витрати непоновлюваної енергії та забезпечують збереження родючості грунтів і сприятливого фітосанітарного стану в агроценозах є актуальними й потребують поглибленого експериментального дослідження. 
Mema - дослідити вплив мінімізації обробітку грунту й елементів біологізації землеробства на продуктивність та якісні показники пшениці озимої, завдяки систематичному застосуванню різних систем обробітку грунту, видів і норм органомінерального удобрення.

\section{Матеріали і методи дослідження.}

Дослідження проводились у двофакторному стаціонарному досліді кафедри грунтознавства та охорони грунтів ім. проф. М. К. Шикули НУБіП України в НДГ «Великоснітинське ім. О. В. Музиченка» Фастівського району Київської області. Дослід закладений в 1998 році і складається iз трьох систем обробітку і трьох систем удобрення (див табл.). Досліджували культуру пшеницю озиму (сорт - Поліська 90). Попередником була кукурудза на силос. Повторність досліду трьохразова, розміщення варіантів рендомізоване в повтореннях. Агротехніка - загальноприйнята для зони. Грунт дослідної ділянки - чорнозем типовий крупнопилувато-середньосуглинковий на лесі. Облік врожаю культур проводили вручну 3 кожного повторення по варіантах iз пробних ділянок загальною площею $15 \mathrm{M}^{2}$ iз наступним зважуванням. У рослинних зразках пшениці озимої визначали вміст білка та "сирої” клейковини - за допомогою аналізатора «Infratec 1225».

\section{Результати дослідження та їх обговорення.}

Пшениця озима $є$ найбільш урожайною зерновою культурою в умовах Правобережного Лісостепу Укра- їни і займає третину посівних площ у сівозміні. Це найцінніша й найбільш розповсюджена зернова продовольча культура. Цінність пшеничного хліба визначається сприятливим хімічним складом зерна. Серед зернових культур пшеничне зерно найбагатше на білки. Вміст їх у зерні м>якої пшениці залежно від сорту та умов вирощування становить у середньому $13-15 \%$.

Озима пшениця є холодостійкою культура. Ïї насіння починає проростати за температури $1-2{ }^{\circ} \mathrm{C}$. Для одержання дружних сходів під час сівби сприятливими $є$ температури $14-16^{\circ} \mathrm{C}$. Також пшениця вимоглива до вологи. Протягом вегетації вологість грунту повинна бути в межах 65-75 \% HB і не знижуватись до рівня вологості розриву капілярів i, тим більше, до вологості в'янення рослин. Транспіраційний коефіцієнт пшениці - 320-450. Він зменшується у разі достатнього застосування фосфорно-калійних добрив, які сприяють розвитку кореневої системи, роздрібному внесенню азотних добрив. Озима пшениця вимагає легкодоступних форм елементів живлення. На утворення 1 ц зерна 3 відповідною кількістю соломи вона забирає 3 грунту 3-4 кг азоту, 1-1,3 кг $\mathrm{P}_{2} \mathrm{O}_{5}, 1,8-2,5$ кг $\mathrm{K}_{2} \mathrm{O}$. Вона добре реагує на внесення мінеральних добрив та післядію органічних - гною й соломи.

Важливе місце в системі землеробства повинні займати також сидерати. Обгрунтоване внесення добрив забезпечує високі врожаї пшениці з підвищеним умістом білку. Озима пшениця досить вибаглива до світла. Похмура погода восени спричиняє неглибоке залягання вузла кущіння та погане загартування, від чого знижується морозо- i 
зимостійкість; навесні - вилягання; під час наливу зерна - зниження вмісту білка в зерні.

Під час порівняння впливу систем удобрення та обробітку грунту на врожайність пшениці озимої (табл. 1) помітно, що незалежно від обробітку грунту найвища врожайність була на варіантах: Гній + NPK та Гній + солома + NPK - 3,74-4,72 т/га. Загалом, внесення мінеральних та органічних добрив на чорноземі типовому підвищило врожайність пшениці озимої порівняно з контролем на 0,28-0,84 т/ га за оранки, на 0,36-1,26 т/га за різноглибинного безполицевого обробітку і на 0,4-1,55 т/га - за мілкого.

Ефективність доз добрив за безполицевих обробітків вища, ніж за оранки. 3 обробітків грунту незначну перевагу мав мілкий безполицевий обробіток на 10-12 см, особливо на варіанті, де вносили гній із мінеральними добривами. На цьому варіанті спостерігалась найвища врожайність $-4,72$ т/га. За різноглибинного обробітку грунту цей показник був нижчим лише на $3 \%$. За іншими варіантами удобрення дещо переважав різноглибинний безполицевий обробіток.

Підвищення якості зерна пшениці - це один з основних шляхів підвищення ефективності сільськогосподарського виробництва. У середньому в зерні пшениці міститься 13,3\% білка, 68,7 вуглеводів, 2 \% жирів, 2,3 клейковини, 1,7 мінеральних речовин, 12 \% води (Гордієнко В. П., Малієнко А. М., Грабак Н. Х., 1998).

\section{1. Урожайність пшениці озимої «Поліська-90» залежно від систем обробітку грунту та удобрення, т/га}

\begin{tabular}{|c|c|c|c|}
\hline $\begin{array}{l}\text { Обробіток } \\
\text { грунту }\end{array}$ & Варіанти удобрення & $\begin{array}{c}\text { Урожай- } \\
\text { ність, т/ } \\
\text { га } \\
\end{array}$ & \begin{tabular}{|c|} 
Прибавка \\
до оран- \\
ки, \pm т/га \\
\end{tabular} \\
\hline \multirow{5}{*}{ Оранка } & Контроль (без добрив) & 3,26 & - \\
\hline & Гній $12 \mathrm{t} / \mathrm{ra}+\mathrm{N}_{55} \mathrm{P}_{45} \mathrm{~K}_{45}$ & 4,10 & - \\
\hline & Гній $(6 \mathrm{t} / \Gamma \mathrm{a})+$ солома $(1,2 \mathrm{~T} / \Gamma \mathrm{a})+\mathrm{N}_{12}+\mathrm{N}_{55} \mathrm{P}_{45} \mathrm{~K}_{45}$ & 4,01 & - \\
\hline & Солома $(2,4 \mathrm{t} / \mathrm{ra})+\mathrm{N}_{55} \mathrm{P}_{45} \mathrm{~K}_{45}$ & 3,84 & - \\
\hline & Солома $(1,2 \mathrm{~T} /$ га $)+\mathrm{N}_{12}+$ сидерати $+\mathrm{N}_{55} \mathrm{P}_{45} \mathrm{~K}_{45}$ & 3,54 & - \\
\hline \multirow{5}{*}{$\begin{array}{l}\text { Глибокий } \\
\text { безпо- } \\
\text { лицевий } \\
\text { обробіток }\end{array}$} & Контроль (без добрив) & 3,31 & $+0,05$ \\
\hline & Гній $12 \mathrm{~T} / \mathrm{\Gamma a}+\mathrm{N}_{55} \mathrm{P}_{45} \mathrm{~K}_{45}$ & 4,57 & $+0,47$ \\
\hline & Гній $(6 \mathrm{t} / г \mathrm{a})+$ солома $(1,2 \mathrm{t} /$ га) $)+\mathrm{N}_{12}+\mathrm{N}_{55} \mathrm{P}_{45} \mathrm{~K}_{45}$ & 4,28 & $+0,27$ \\
\hline & Солома $(2,4 \mathrm{t} / \mathrm{ra})+\mathrm{N}_{5} \mathrm{P}_{45} \mathrm{~K}_{45}$ & 4,14 & $+0,30$ \\
\hline & Солома $(1,2 \mathrm{~T} / \mathrm{ra})+\mathrm{N}_{12}+$ сидерати $+\mathrm{N}_{55} \mathrm{P}_{45} \mathrm{~K}_{45}$ & 3,67 & $+0,13$ \\
\hline \multirow{5}{*}{$\begin{array}{l}\text { Мілкий } \\
\text { безпо- } \\
\text { лицевий } \\
\text { обробіток }\end{array}$} & Контроль (без добрив) & 3,17 & $-0,14$ \\
\hline & Гній $12 \mathrm{~T} / \mathrm{ra}+\mathrm{N}_{55} \mathrm{P}_{5} \mathrm{~K}_{45}$ & 4,72 & $+0,15$ \\
\hline & Гній $(6 \mathrm{t} / г \mathrm{a})+$ солома $(1,2 \mathrm{t} /$ га) $)+\mathrm{N}_{12}+\mathrm{N}_{55} \mathrm{P}_{45} \mathrm{~K}_{45}$ & 3,74 & $-0,54$ \\
\hline & Солома $(2,4 \mathrm{t} / \mathrm{ra})+\mathrm{N}_{55} \mathrm{P}_{5} \mathrm{~K}_{45}$ & 3,57 & $-0,57$ \\
\hline & Солома $(1,2 \mathrm{~T} / \mathrm{ra})+\mathrm{N}_{12}+$ сидерати $+\mathrm{N}_{55} \mathrm{P}_{45} \mathrm{~K}_{45}$ & 3,75 & $+0,58$ \\
\hline
\end{tabular}

НIP05, т/га для удобрення 0,25

для обробітку $\quad 0,22$ 
Зерно пшениці може слугувати одним із головних джерел енергії для людини, а також джерелом білка, вітамінів $\mathrm{B}_{1}, \mathrm{~B}_{2}, \mathrm{~B}_{3}$, РP, а також сполук фосфору та заліза. Хімічний склад зерна пшениці залежить від грунтово-кліматичних факторів, умов вирощування, сортових властивостей.

Сорт Поліська-90 відноситься до сильних і цінних сортів м'якої пшениці, що свідчить про генетично закладений високий уміст білка, клейковини та гарні хлібопекарські властивості. У нашому випадку на урожайність та показники якості озимої пшениці вплинули обробіток грунту та удобрення, а також сприятливі погодні умови протягом вегетаційного періоду.
Як видно $з$ таблиці 2, найбільше на якісні показники пшениці озимої вплинуло внесення добрив. Значно менше - обробіток грунту. Відомо, що забезпеченням рослин поживними речовинами впродовж всієї вегетації можна отримати більший врожай із гарними технологічними показниками зерна.

Найкращі показники якості виявилися на варіанті $з$ традиційним органо-мінеральним удобренням та із застосуванням гною, соломи на фоні NPK. Загалом уміст білка та клейковини відповідали нормам якості цінної й сильної пшениці: вміст білка на удобрюваних варіантах був у межах 14,3-15,5 \% (сильна пшениця), на контролі - 13,3-13,6 (цінна). Уміст клейковини відповідно - 29,4-31,9\% (сильна) та 27,3-27,9 (цінна).

\section{2. Показники якості пшениці озимої «Поліська-90» залежно від систем обробітку та удобрення}

\begin{tabular}{|c|c|c|c|}
\hline $\begin{array}{l}\text { Система } \\
\text { обробітку }\end{array}$ & $\begin{array}{c}\text { Варіанти } \\
\text { удобрення }\end{array}$ & $\begin{array}{c}\text { Уміст } \\
\text { білку, \% }\end{array}$ & $\begin{array}{l}\text { Уміст клей- } \\
\text { ковини, \% }\end{array}$ \\
\hline \multirow{5}{*}{ Оранка } & Контроль (без добрив) & 13,6 & 27,3 \\
\hline & Гній (12 т/га) $+\mathrm{N}_{55} \mathrm{P}_{45} \mathrm{~K}_{45}$ & 15,1 & 30,7 \\
\hline & Гній (6 т/га) + солома $\left(1,2\right.$ т/га) $+\mathrm{N}_{12}+\mathrm{N}_{55} \mathrm{P}_{45} \mathrm{~K}_{45}$ & 15,0 & 30,8 \\
\hline & Солома $(2,4 \mathrm{~T} / \mathrm{ra})+\mathrm{N}_{55} \mathrm{P}_{45} \mathrm{~K}_{45}$ & 14,3 & 29,4 \\
\hline & Солома $(1,2 \mathrm{~T} / г \mathrm{a})+\mathrm{N}_{12}+$ сидерати $+\mathrm{N}_{55} \mathrm{P}_{45} \mathrm{~K}_{45}$ & 14,9 & 30,2 \\
\hline \multirow{5}{*}{$\begin{array}{l}\text { Глибокий } \\
\text { безполице- } \\
\text { вий }\end{array}$} & Контроль (без добрив) & 13,4 & 27,5 \\
\hline & Гній (12 т/га) $+\mathrm{N}_{55} \mathrm{P}_{45} \mathrm{~K}_{45}$ & 15,3 & 31,0 \\
\hline & Гній (6 т/га) + солома $(1,2$ т/га $)+\mathrm{N}_{12}+\mathrm{N}_{55} \mathrm{P}_{45} \mathrm{~K}_{45}$ & 15,2 & 30,6 \\
\hline & Солома $(2,4$ т/га) + N55P45K45 & 14,6 & 29,7 \\
\hline & Солома $\left(1,2\right.$ т/га) + N12 + сидерати $+\mathrm{N}_{55} \mathrm{P}_{45} \mathrm{~K}_{45}$ & 14,9 & 30,8 \\
\hline \multirow{5}{*}{$\begin{array}{l}\text { Мілкий } \\
\text { безпо- } \\
\text { лицевий } \\
\text { обробіток }\end{array}$} & Контроль (без добрив) & 13,3 & 27,9 \\
\hline & Гній (12 т/га) $+\mathrm{N}_{55} \mathrm{P}_{45} \mathrm{~K}_{45}$ & 15,5 & 31,9 \\
\hline & Гній (6 т/га) + солома $\left(1,2\right.$ т/га) $+\mathrm{N}_{12}+\mathrm{N}_{55} \mathrm{P}_{45} \mathrm{~K}_{45}$ & 15,4 & 31,0 \\
\hline & Солома $(2,4 \mathrm{~T} / \mathrm{ra})+\mathrm{N}_{55} \mathrm{P}_{45} \mathrm{~K}_{45}$ & 14,8 & 30,0 \\
\hline & Солома $(1,2 \mathrm{~T} / г \mathrm{a})+\mathrm{N}_{12}+$ сидерати $+\mathrm{N}_{55} \mathrm{P}_{45} \mathrm{~K}_{45}$ & 15,0 & 30,6 \\
\hline
\end{tabular}


Існує залежність, що чим більша урожайність пшениці озимої, тим вищий вміст білка, що підтвердилося і нашими показниками. Варіантом 3 найбільшим вмістом білка виявився Гній + NPK за мілкого безполицевого обробітку i склав 15,5\%. Вміст клейковини також найвищим на цьому варіанті - 31,9 \%.

\section{Висновки і перспективи.}

Отже, систематичне застосування ресурсоощадних технологій вирощування сільськогосподарських культур із мінімізацією обробітку грунту й елементами біологізації сприяє підвищенню урожайності пшениці озимої та покращенню показників якості зерна. Так, найвищу урожайність пшениці озимої (4,72 т/га) отримали на фоні органо-мінерального удобрення із застосуванням гною за мілкого безполицевого обробітку грунту й дещо нижчу - за глибокого у порівнянні з оранкою. Ефективність доз добрив за безполицевих обробітків на чорноземі типовому була вищою, ніж за оранки. Внесення мінеральних та органічних добрив підвищило врожайність пшениці озимої порівняно $з$ контролем на 0,28-0,84 т/га за оранки, на 0,36-1,26 т/га за різноглибинного безполицевого обробітку і на 0,4-1,55 т/га - за мілкого. Найкращі показники якості виявилися на варіанті із традиційним органо-мінеральним удобренням та із застосуванням гною, соломи на фоні NPK.

\section{References}

1. Hromov O. Zerno Ukrainy: rekord urozhaiu bude podolano. Hazeta Kabinetu Ministriv Ukrainy "Uriadovyi kur'ier". Available at: https:// ukurier.gov.ua/uk/articles/zerno-ukrayini-rekord-urozhayu-bude-podolano/

2. Lebid Ye.M., Cherenkov A. V., Solodushko M. M. (2008) Osoblyvosti vyroshchuvannia ozymoi pshenytsi u Stepu Ukrainy.[Features of winter wheat cultivation in the Steppe of Ukraine]. Nauk.-tekhn. biul. MIP, 8, 335-344.

3. Markovska O.Ye., Maliarchuk M. P. (2017). Ahroekonomichna otsinka system osnovnoho obrobitku gruntu ta udobrennia $v$ sivozmini za umov zroshennia na Pivdni Ukrainy. [Agroeconomic assessment of systems of basic tillage and fertilization in crop rotation under irrigation conditions in the south of Ukraine]. Tavriiskyi naukovyi visnyk: Silskohospodarski nauky / DVNZ «Kherson. derzh. ahrar. un-t», 88-95.

4. Vozhehova R.A., Kryvenko A.I. (2019). Produktyvnist ta enerhetychna efektyvnist tekhnolohii vyroshchuvannia ozymykh zernovykh kultur. [Productivity and energy efficiency of winter grain growing technology]. Mizhvidomchyi tematychnyi naukovyi zbirnyk "Zroshuvane zemlerobstvo", 71, 27-31.

5. Maliarchuk M. P., Vozhehova R. A., Markovska O. Ye. (2012). Formuvannia system osnovnoho obrobitku gruntu $v$ ahrobioheotsenozakh na meliorovanykh zemliakh pivdennoi posushlyvoi ta sukhostepovoi gruntovo-ekolohichnykh pidzon Ukrainy: navch. posibnyk. [Formation of systems of basic tillage in agrobiogeocenoses on the reclaimed lands of the southern arid and dry-steppe soil-ecological subzones of Ukraine]. Kherson: Ailant, 180.

6. Vozhehova R. A., Stashuk V. A., Zaryshniak A. S. (2014). Systemy zemlerobstva na zroshuvanykh zemliakh. [Irrigation systems for irrigated land]. Kyiv: Ahrarna nauka, 360.

7. Kolomiiets M.V. (2003). Pidvyshchennia vrozhainosti polovykh kultur pry riznomu systemnomu obrobitku gruntu. [Improving the yield of field crops with different soil tillage]. Zemlerobstvo: mizhvidomchyi tematychnyi naukovyi zbirnyk, 75, 61-67.

8. Hordiienko V. P., Maliienko A. M., Hrabak N. Kh. (1998). Prohresyvni systemy obrobitku gruntu. [Progressive soil tillage systems]. za red. V.P. Hordiienka. Simferopol, 272. 


\section{K. S. Karabach (2019). YIELD CAPACITY AND QUALITY INDICATORS OF WINTER} WHEAT DEPENDING ON SYSTEMS OF BASIC TREATMENT OF SOIL AND FERTILIZER.

PLANT AND SOIL SCIENCE, 10(3): 42-48. https://doi.org/10.31548/agr2019.03.042

Annotation. The influence of the application of different systems of primary tillage (plowing, shallow tillage without overturning, deep tillage without overturning) and fertilizer levels on the yield and quality indicators of winter wheat grain is studied. Studies have shown that in the conditions of the Right-Bank Forest-Steppe of Ukraine, systematic tillage without overturning increases the yield and quality of winter wheat grain at all levels of fertilizer compared to traditional plowing with overturning. The application of organic and mineral fertilizers on typical chornozem positively affects the yield of winter wheat, increasing it compared to control by 0.28-0.84 $\mathrm{t} / \mathrm{ha}$ for plowing, by 0.36-1.26 $\mathrm{t} / \mathrm{ha}$ for deep tillage without overturning, and 0.4-1.55 t/ha for shallow tillage without overturning. It was revealed that the highest crop yield (4.72 t/ha) was obtained with shallow cultivation of the soil against the background of organic-mineral fertilizer with the use of manure, and with deep tillage without overturning this indicator was only 3\% lower. In general, the protein and gluten content on the fertilized variants corresponded to the quality standards of strong, and in the control - valuable wheat. The highest quality indicators of winter wheat grains were noted in the variant with traditional organic-mineral fertilizer (manure + NPK) under shallow tillage: protein content was $15.5 \%$ and gluten content $-31.9 \%$, which corresponds to the first quality group.

Keywords: winter wheat, tillage, soil, fertilizers, grain quality 